\title{
PERAN SOSIALISASI DALAM MEMEDIASI PENGARUH PERSEPSI DAN SIKAP BURUH TERHADAP PARTISIPASI PADA LAYANAN PROTEKSI KETENAGAKERJAAN
}

\author{
Ni Wayan Trisna Yundhari ${ }^{1}$ \\ A.A.I.N Marhaeni \\ I Gusti Bagus Indrajaya ${ }^{3}$ \\ ${ }^{1,2,3}$ Fakultas Ekonomi dan Bisnis Universitas Udayana, Bali, Indonesia \\ e-mail: trisnayundhari71@gmail.com
}

\begin{abstract}
ABSTRAK
Upaya pemberian perlindungan terhadap kesehatan, keselamatan, dan kesejahteraan tenaga kerja adalah untuk meningkatkan taraf hidup tenaga kerja dan keluarganya di kehidupan yang mendatang. Penelitian ini merupakan penelitian kualitatif dan kuantitatif yang dianalisis secara deskripsi dengan mendeskripsikan atau menggambarkan data yang telah terkumpul yang dilakukan di Kecamatan Blahbatuh, Kabupaten Gianyar. Teknik analisis penelitian ini menggunakan dua metode analisis data. Pertama, dengan menggunakan metode analisis faktor untuk mendeskrispikan sebuah keadaan atau sebuah konsep, variable-variabel yang direncanakan akan diperlakukan sebagai indikator baik dari variable laten independen maupun laten dependen. Kedua, dengan menggunakan metode analisis jalur (path analysis) untuk mengetahui pola hubungan antara tiga atau lebih dan tidak dapat digunakan untuk mengkonfirmasi atau menolak hipotesis. Sampel yang digunakan dalam penelitian ini sebanyak 99 responden. Hasil analisis menunjukkan bahwa tingkat partisispasi buruh dilihat dari indikator persepsi buruh, sikap buruh, dan keikutsertaan sosialisasi di Kecamatan Blahbatuh, Kabupaten Gianyar tergolong positif. Hal ini dilihat dari rata-rata skor yang diperoleh dari masing-masing indikator, persepsi buruh, sikap buruh, dan sosialisasi buruh, serta partisipasi buruh. Dilihat secara tidak langsung persepsi buruh dan sikap buruh berpengaruh positif dan signifikan terhadap partisipasi dalam layanan proteksi ketenagakerjaan melali keikutsertaan sosialisasi dalam layanan proteksi ketenagakerjaan di Kecamatan Blahbatuh, Kabupaten Gianyar.
\end{abstract}

Kata kunci: Persepsi Buruh, Sikap Buruh, Sosialisasi Buruh, Partisipasi Buruh

\begin{abstract}
This research is a qualitative and quantitative research which is analyzed in descriptions by describing or describing the collected data conducted in Blahbatuh District, Gianyar Regency. Analytical techniques of this study using two methods of data analysis. First, by using factor analysis methods to describe a state or a concept, the planned variables will be treated as indicators of either the latent independent variable or the latent dependent. Secondly, by using path analysis method to know the relationship pattern between three or more and can not be used to confirm or reject the hypothesis. The sample used in this study were 99 respondents. The result of the analysis shows that the level of labor participation is seen from labor perception indicator, labor attitude, and socialization participation in Blahbatuh sub-district, Gianyar regency is positive. This is seen from the average score obtained from each indicator, labor perception, labor attitude, and socialization of labor, and labor participation. Indirectly, workers' perceptions and worker attitudes have a positive and significant influence on participation in labor protection services to explore the participation of socialization in labor protection services in Blahbatuh sub-district, Blahbatuh sub-district.
\end{abstract}

Keywords: Labor Perception, Labor Attitude, Labor Socialization, Labor Participation 


\section{PENDAHULUAN}

Tingginya pekerja sektor informal di Indonesia menjadi tantangan tersendiri bagi pemerintah dalam menyelenggarakan Jaminan Sosial yang mana sudah menjadi hak setiap warga negara. Memiliki persentase penduduk berpenduduk yang tinggi di sektor informal telah menjadi ciri penting pasar tenaga kerja Indonesia selama beberapa dekade. Tapi struktur ini telah berubah cukup cepat dalam mendukung sektor formal, walaupun tidak jelas apakah ini lebih baik (Xue,2017).Sebagaimana diatur dalam UU Nomor 40 Tahun 2004 bahwa setiap pekerja wajib mendapatkan Jaminan Sosial Nasional. Upaya pemberian perlindungan terhadap kesehatan, keselamatan, dan kesejahteraan tenaga kerja adalah untuk meningkatkan taraf hidup tenaga kerja dan keluarganya di kehidupan yang mendatang (Henny dkk,2010).

Kemajuan ekonomi dengan adanya jaminan sosial, perbaikan lingkungan hidup dan majunya ilmu pengetahuan, terutama karena kemajuan ilmu kedokteran, mampu meningkatkan angka harapan hidup (life expectancy)(Dewi,2014).Hak atas perlindungan sosial diakui dalam Deklarasi Universal Hak Asasi Manusia tahun 1948 juga, sebagaimana pasal 22 menyebutkan, "Setiap orang, sebagai anggota masyarakat, memiliki hak atas jaminan sosial dan berhak mendapatkan realisasi melalui upaya nasional dan kerjasama internasional(Shahnewaz, et, al, 2013).Perlindungan sosial telah muncul sebagai kerangka kebijakan yang digunakan untuk menangani kemiskinan dan kerentanan di negara-negara berkembang (Barrentos, 2011) 
Program perlindungan sosial telah berkembang pesat di negara berkembang dalam beberapa tahun terakhir(Sarah dan jonathan, 2014) Jaminansosial merupakan kebijakan untuk memberikan tunjangan pendapatan (incomesupport) bagi masyarakat karena situasi yang mendesak maupun situasi yang sudah diperkirakan sebelumnya (life cycle); misalnya: tunjangan bagi orang cacat yang diakibatkan oleh kecelakaan sehingga tidak bisa bekerja atau pensiun bagi orang yang telah memasuki usia pensiun. Jaminan sosial merupakan hal penting bagi para pekerja tenaga kerja sektor informal non pertanian yang memiliki resiko kecelakaan kerja yang tinggi.Sementara beberapa orang mungkin meragukan manfaat yang akan diberikan asuransi kesehatan nasional kepada penduduk Indonesia, terutama kepada masyarakat miskin dan rentan. (Sato dan Arie, 2015).

Perlindungan sosial pada agenda pembangunan kini menjadi fakta yang mapan, di mana bangkitnya perlindungan sosial ini telah terjadi saat ini mengenai perlindungan sosial sekaligus mengawasi kembalinya pendekatan pembangunan yang sebagian didorong oleh peran internasional baru negara-negara berkembang. Dengan adanya sektor infomal maka lapangan pekerjaan juga bertambah, namun kebanyakan terjadi di sektor-sektor rendah keterampilan yang cenderung informal (Coxhead dan Roshes, 2016).

Jaminan sosial sangat penting bagi pekerja, keluarganya dan masyarakat secara keseluruhan.Jaminan sosial merupakan hak asasi dan menjadi alat penting untuk membentuk kohesisosial, sehingga membantu terwujudnya perdamaian dan kesatuan sosial. Melalui solidaritas dan pembagianbeban yang adil, jaminan sosial 
memberi kontribusi pada martabat manusia, persamaan hakdan keadilan sosial (ILO,2008). Kebijakan Jaminan Kesehatan Nasional kebijakan untuk memberikan asuransi pekerja memberikan hasil yang lebih konsisten daripada keputusan mereka hubungan individu (Bozkaya dan William,2009).

International Labour Organization (ILO) (2002) dalam "Social Security and Coverage for All', perlindungan sosial merupakan konsep yang luas yang juga mencerminkan perubahan-perubahan ekonomi dan sosial pada tingkat internasional. Konsep ini termasuk jaminan sosial (social security) dan skemaskema swasta. Lebih jauh, dijelaskan bahwa sistem perlindungan sosial bisa dibedakan dalam 3 (tiga) lapis (tier): Lapis (tier) Pertama merupakan jejaring pengaman sosial yang didanai penuh oleh pemerintah; Lapis Kedua merupakan skema asuransi sosial yang didanai dari kontribusi pemberi kerja (employer) dan pekerja; dan Lapis Ketiga merupakan provisi suplementari yang dikelola penuh oleh swasta.

ILO (2002) menyebutkan bahwa jaminan sosial merupakan bentuk perlindungan yang disediakan dalam suatu masyarakat untuk masyarakat itu sendiri melalui berbagai upaya dalam menghadapi kesulitan keuangan yang dapat terjadi karena kesakitan, kelahiran, pengangguran, kecacatan, lanjut usia, ataupun kematian. Perlindungan kerja dan tunjangan pengangguran dipertimbangkansebagai perangkat asuransi yang paling menonjol bagi para pekerja untuk dilindungidiri mereka terhadap risiko pengangguran (Neugart, 2007). Kesadaran dan persepsi tentang asuransi kesehatan masih sangat awal. Meski asuransi kesehatanBukan konsep baru dan orang juga semakin 
mengenalnya, namun kesadaran ini belum sampai pada tingkatberlangganan produk asuransi kesehatan (Suwarna, et, al, 2012)

Kabupaten Gianyar merupakan salah satu daerah di Kabupaten Gianyar yang memiliki sektor informal yang banyak dan beragam. Seperti usaha kerajinan dan kuliner. Kecamatan Blahbatuh adalah salah satu kecamatan di Kabupaten Gianyar dengan sejumlah tenaga sektor informal sangat banyak. Berdasarkan hasil observasi awal di Kecamatan Blahbatuh banyak tenaga kerja sektor informal di bidang industri, kerajinan, dan Buruh yang memiliki resiko kerja tinggi.

Adanya keterbatasan informasi yang diterima oleh para tenaga kerja sektor infromal, tingkat pendapatan yang dikatakan mampu untuk membayar iuran setiap bulan, dan tinggi rendahnya tingkat pendidikan juga berpengaruh terhadap persepsi dan sikap buruh terhadap layanan proteksi ketenagakerjaan.Scarpetta (2014) mengatakan Reformasi perlindungan ketenagakerjaan seharusnya dilakukan bagian dari paket komprehensif yang mempromosikan alokasi tenaga kerja dan kemampuan adaptasi yang lebih baik di pasar tenaga kerja, tetapi juga menyediakan jaring pengaman untuk layanan tenaga kerja yang menganggur dan efektif.

Selain itu faktor adat istiadat dikeluarga atau kebiasaan yang ada dikeluarga menyebabkan kurangnya informasi yang diterima karena sudah terbiasa menggunakan Jaminan Sosial yang dibuat oleh pemerintah. Oleh karena itu adanya sosialisasi, persepsi dan sikap buruh terhadap layanan proteksi ketenagakerjaan sangat diperlukan guna memutuskan rantai sebab akibat terjadinya kecelakaan kerja. 
Perlindungi untuk tenaga kerja sektor informal dari hilangnya pendapatan di hari tua akibat adanya kecelakaan kerja. Pekerja di sektor informal diketahui tidak memiliki skema pensiun jaminan sosial formal. Salah satu alasannya adalah mengatur skema umum yang sulit untuk sektor informal dan formal dalam hal kontribusi dan tunjangan. Akibatnya, sebagian besar pekerja sektor informal bergantung pada skema informal seperti dukungan keluarga, tabungan dan pinjaman pribadi setelah masa pensiun mereka sehingga membuat mereka rentan terhadap kemiskinan(Mohd,2015).

Menurut teori Domino Heinrich penyebab kecelakaan kerja sebanyak 85 90 persen disebabkan karena adanya human error atau kesalahan manusia itu sendiri(Nasrullah,2014). Kurangnya tingkat pendidikan tenaga kerja sektor informal juga berpengaruh terhadap kurang nya informasi yang diterima oleh tenaga kerja. Sementara ini untuk tenaga kerja sektor informal iuran kecelakaan kerja sudah dipotong langsung memalui gaji yang diterima setiap bulannya. Rendahnya tingkat pedidikan dan tingkat pendapatan yang dimiliki tenaga kerja sektor informal ini juga sangat berpengaruh terhadap Kurangnya sikap (Attitude), pengetahuan (Knowlegde), dan persepsi tenaga kerja sektor informal ini terhadap Jaminan Kecelakaan Kerja (JKK).

Sikap para pekerja juga sering mengeluhkan besarnya hambatan birokrasi yang dihadapiapabila mereka mengajukan klaim ke PT Jamsostek. Hanyaprogram jaminan kesehatan saja yang dianggap relatif bersih dari masalah tersebut.Karena faktor-faktor tersebut di atas, sebagian besar pekerja yang mengikuti programJamsostek menganggap pungutan Jamsostek sebagai suatu pajak, 
bukanlah suatujaminan sosial untuk mereka.Karenaketidakpercayaan pekerja ini, terdapat kecenderungan bagi pekerja untukmengambil pensiun dini, seperti yang terjadi pada saat krisis ekonomi melandaIndonesia mulai tahun 1997. Dalam hal ini, dana Jamsostek ternyata telah menjadi pengganti (substitute) bagi dana asuransi pengangguran, yang sampai saat ini belumada di Indonesia (ILO, 2003).

Adapun tujuan penelitian 1) Untuk menganalisis pengaruh persepsi buruh dan sikap buruh tentang layanan proteksi ketenagaekerjaan terhadap keikutsertaan dalam sosialisasi layanan proteksi ketenagakerjaan di Kecamatan Blahbatuh, Kabupaten Gianyar. 2) Untuk menganalisis pengaruh persepsi buruh, sikap buruh tentang layanan proteksi ketenagakerjaan, dan keikutsertaan dalam sosialisasi layanan proteksi ketenagakerjaan terhadap partisipasi buruh dalam layanan proteksi ketenagakerjaan di Kecamatan Blahbatuh, Kabupaten Gianyar. 3) Untuk menganalisis peran keikutsertaan sosialisasi layanan proteksi ketenagakerjaan dalam memediasi pengaruh persepsi dan sikap buruh tentang layanan proteksi ketenagakerjaan terhadap partisipasi buruh dalam layanan proteksi ketenagakerjaan di Kecamatan Blahbatuh, Kabupaten Gianyar.

Sektor informal memiliki ciri-ciri mudah keluar masuk pekerjaan, mengusahakan menggunakan bahan baku lokal tanpa berdasarkan hukum formal, jangkauan operasionalnya sempit, kegiatannya bersifat padat karya dengan menggunakan teknologi yang masih sederhana (tradisional), pekerja yang terlibat di sektor informal memiliki tingkat pendidikan formal yang rendah dan keahlian yang kurang memadai, kondisi pasar sangat menyangkut hubungan antara penjual dan pembeli yang bersaing dan bersifat personal dimana keadaanya tidak teratur. 
Sektor informal adalah sektor yang tidak terorganisasi (unorganized), tidak teratur (unregulated), dan kebanyakan legal tetapi tidak terdaftar (unregistered). Di Negara Sedang Berkembang, sekitar 30-70 persen populasi tenaga kerja di perkotaan bekerja di sektor informal. Sektor informal memiliki karakteristik seperti jumlah unit usaha yang banyak dalam skala kecil; kepemilikan oleh individu atau keluarga, teknologi yang sederhana dan padat tenagakerja,tingkatpendidikan dan ketrampilan yang rendah, akses ke lembaga keuangan daerah, produktivitas tenaga kerja yang rendah dan tingkat upah yang juga relatif lebih rendah dibandingkan sektor formal(Adam, 2014).Sektor informal juga meliputi berbagai kegiatan usaha yang tidak memiliki perlindungan oleh badan hukum (Danendra, 2015).

Istilah sektor informal biasanya digunakan untuk menunjukkan sejumlah kegiatan ekonomi yang berskala kecil, karena di negara sedang berkembang sektor informal dianggap sebagai suatu manifestasi situasi pertumbuhan kesempatan kerja. ILO (1973) dalam Seftiani (2010) menggambarkan sektor informal sebagai sektor yang mencakup bidang-bidang usaha yang mudah dimasuki, menggunakan sumber daya setempat, dimiliki oleh kerabat dan berskala kecil, menggunakan tenaga kerja intensif dan teknologi yang telah diadaptasi, para pekerja di sektor ini tidak menuntut keterampilan yang berasal dari pendidikan formal dan usaha-usaha tersebut beroperasi dalam keadaan pasar yang tidak terkendali dan kompetitif.Menurut ILO dalam Nindy (2016), antara lain: i) selururh aktivitasnya bersandara pada sumber daya sekitar, (ii) skala usahanya relatif kecil dan merupakan usaha keluarga, (iii) aktivitasnya ditopang oleh 
teknologi tepat guna dan bersifat padat karya, (iv) tenaga kerjanya terlatih dalam pola-pola tidak resmi, (v) seluruh aktivitasnya berada diluar aturan yang diatur pemerintah, dan (vi) aktivitasnya di dalam pasar sangat bersaing.

Bimo Walgito (2004) mengungkapkan bahwa persepsi merupakan suatu proses pengorganisasian, penginterpretasian terhadap stimulus yang diterima oleh organisme atau individu sehingga menjadi sesuatu yang berarti, dan merupakan aktivitas yang integrated dalam diri individu. Respon sebagai akibat dari persepsi dapat diambil oleh individu dengan berbagai macam bentuk. Stimulus mana yang akan mendapatkan respon dari individu tergantung pada perhatian individu yang bersangkutan. Berdasarkan hal tersebut, perasaan, kemampuan berfikir, pengalaman-pengalaman yang dimiliki individu tidak sama, maka dalam mempersepsi sesuatu stimulus, hasil persepsi mungkin akan berbeda antar individu satu dengan individu lain.

Persepsi seseorang atau kelompok dapat jauh berbeda dengan persepsi orang atau kelompok lain sekalipun situasinya sama. Perbedaan persepsi dapat ditelusuri pada adanya perbedaan-perbedaan individu, perbedaan-perbedaan dalam kepribadian, perbedaan dalam sikap atau perbedaan dalam motivasi. Pada dasarnya proses terbentuknya persepsi ini terjadi dalam diri seseorang, namun persepsi juga dipengaruhi oleh pengalaman, proses belajar, dan pengetahuannya.

Menurut Notoatmodjo (2010) dalamNasrullah, dkk (2014), sikap merupakan suatu keinginan untuk bertindak dan berpersepsi. Sikap merupakan respon yang melibatkan faktor pendapat dan emosi seseorang terhadap suatu objek.Sikap memiliki tiga komponen pokok, antara lain (1) kepercayaan, ide dan 
konsep terhadap objek; (2) kehidupan emosional atau evaluasi terhadap suatu objek; (3) Kecederungan untuk melakukan tindakan. Ketiga komponen tersebut akan saling mendukung dan bersama-sama akan membentuk suatu sikap secara utuh.

Partisipasi masyarakat adalah ikut sertanya seluruh anggota masyarakat dalam memecahkan permasalahan-permasalahan masyarakat tersebut. Partisipasi masyarakat di bidang kesehatan berarti keikutsertaan seluruh anggota masyarakat dalam memecahkan masalah kesehatan mereka sendiri. Partisipasi masyarakat tentunya dipengaruhi oleh keadaaan sosial masyarakat yang bersangkutan, Partisipasi dapat bersifat aktif maupun pasif, partisipasi bersifat pasif berarti sikap, prilaku, dan tindakan yang dilakukan seseorang dengan tidak menganggu kegiatan pembangunan. Sedangkan partisipasi yang bersifat aktif seperti: ikut berpartisipasi dalam setiap kegiatan yang ada (Ratiabriani, 2016) Di dalam hal ini, masyarakat sendirilah yang aktif memikirkan, merencanakan, melaksanakan, dan mengevaluasikan program-program kesehatan masyarakatnya. Institusi kesehatan hanya sekadar memotivasi dan membimbingnya (Notoatmodjo, 2007).Partisipasi berarti peran serta seseorang atau kelompok masyarakat dalam proses pembangunan baik dalam bentuk pernyataan maupun dalam bentuk kegiatan dengan memberi masukan pikiran, tenaga, waktu, keahlian, modal dan atau materi, serta ikut memanfaatkan dan menikmati hasil-hasil pembangunan (Sumaryadi, 2010).

Abdullah (2016) menyatakan bahwa partisipasi seseorang sangat dipengaruhi oleh sikap dan adanya keikutsertaan sosialisasi.Partisipasi masyarakat 
menghendaki adaya kontribusi terhadap kepentingan atau tujuan kelompok dalam hal pembangunan. Partisipasi masyarakat dapat di operasionalkan melalui indikator sebagai berikut(Andreeyan,2014): 1) Pemikiran (Mind), 2) Uang (Money), 3) Material (Material), 4) Tenaga (Manpower). Widnyani (2016) adanya partisipasi yang positif dilihat dari adanya keikutsertaan sosialisasi yang positif. Adanya keikutsertaan sosialisai yang tinggi akan mendorong adanya partisipasi yang meningkat pada masyarakat.

Program Jaminan Kecelakaan Kerja (JKK), misalnya, memberikan perlindungan kepada peserta BPU terhadap resiko kecelakaan yang terjadi saat bekerja. Perlindungan terhadap kecelakaan kerja dimulai sejak pekerja meninggalkan rumah, saat sedang bekerja, hingga kembali lagi ke rumah. Dengan cakupan yang demikian luas, pekerja diharapkan dapat bekerja dengan tenang serta merasa aman karena perlindungan maksimal dari program Jaminan Kecelakaan Kerja. Apabila terjadi kecelakaan saat bekerja, manfaat yang didapatkan oleh pekerja berupa biaya perawatan di rumah sakit hingga Rp. 20 juta. Jika terjadi resiko meninggal dunia karena kecelakaan kerja, maka ahli waris dari pekerja berhak mendapatkan santunan sebesar 48 kali gaji yang terdaftar dan santunan berkala sebesar Rp. 200 ribu per bulan selama dua tahun.

Memberikan perlindungan atas risiko-risiko kecelakaan yang terjadi dalam hubungan kerja, termasuk kecelakaan yang terjadi dalam perjalanan dari rumah menuju tempat kerja atau sebaliknya dan penyakit yang disebabkan oleh lingkungan kerja.Iuran dibayarkan oleh pemberi kerja yang dibayarkan (bagi peserta penerima upah), tergantung pada tingkat risiko lingkungan kerja, yang 
besarannya dievaluasi paling lama 2 (tahun) sekali.kebijakan perlindungan sosial harus didasarkan pada nilai keadilan sosial dan hak asasi manusia, melembagakan kebijakan sosial jangka panjang yang mendapatkan keuntungan dari dukungan politik berbasis luas dan didasarkan pada mekanisme pembiayaan yang berkelanjutan (Hujo dan Elena, 2011).

Willingness to pay pada umumnya diartikan sebagai kesediaan pengguna untuk mengeluarkan imbalan (dalam bentuk uang) atas jasa yang diperolehnya. WTP dapat diartikan sebagai kesediaan seseorang untuk membayar terhadap barang dan jasa (Emalia, 2016).Willingness to pay juga diartikan sebagai jumlah maksimum yang akan dibayarkan konsumen untuk menikmati peningkatan kualitas (Whitehead, 2005). Analisis WTP didasarkan pada persepsi pengguna terhadap tarif atas jasa pelayanan angkutan umum yang dipengaruhi oleh beberapa faktor (Permata, 2012) yaitu kuantitas dan kualitas jasa transportasi, utilitas pengguna, dan penghasilan pengguna. Kesediaan untuk membayar (willingness to pay) memiliki pengertian: kesediaan masyarakat untuk menerima beban pembayaran, sesuai dengan besarnya jumlah yang telah ditetapkan oleh pemerintah. Willingness to pay penting untuk melindungi konsumen dari penyalahgunaan kekuasaan monopoli yang dimiliki perusahaan dalam penyediaan produk berkualitas dan harga.Puspita sari dalam Jurnal Studi ekonomi dan Pembangunan(2015) menyakan Willingness to pay dapat diperkirakan dengan menggunakan pendekatan contingent valuation method (CVM).

Ability to pay adalah kemampuan seseorang untuk membayar suatu jasa berdasarkan penghasilan yang didapat (Rumiati,dkk. 2013). Ability to pay juga 
dapat didefinisikan sebagai batas maksimum kemampuan dari penghasilan seseorang yang dialokasikan untuk membayar jasa yang diterimanya. Pendekatan yang digunakan dalam menganalisis nilai ATP didasarkan pada alokasi dana untuk transportasi dan intensitas perjalanan. Sangatlah wajar bagi seseorang yang memiliki nilai ATP rendah memiliki nilai WTP yang tinggi karena nilai WTP ditentukan oleh pertimbangan psikologis pengguna (Ajzen, Rosenthal dan Brown, 2000). Nilai ATP menunjukkan batas maksimum kemampuan seseorang membayar ongkos dalam sekali perjalanan. Faktor-faktor yang mempengaruhi besaran nilai ATP menurut Permata (2012) adalah penghasilan keluarga per bulan, alokasi dana untuk transportasi, intensitas perjalanan dan jumlah anggota keluarga. Dalam penentuan tarif angkutan sering terjadi ketidaksesuaian antara ATP dan WTP.

Cakupan strategi komunikasi meliputi tujuh aspek pokok berikut; penetapan khalayak sasaran, metode komunikasi, pesan komunikasi, penggunaan saluran, penetapan komunikator, tata kelola dan pengambilan keputusan serta monitoring dan evaluasi (Juvita, dkk 2015). Komunikasi Publik Terintegrasi Program Jaminan Sosial Bidang Ketenagakerjaan dilakukan dengan empat teknik berikut: Advokasi dilakukan dengan tujuan membangun kepedulian dan komitmen, Edukasi merupakan proses pembelajaran yang diarahkan pada perubahan sikap dan perilaku dari penerima informasi melalui penyebaran informasi, persuasi, dan edukasi secara terus menerus., Sosialisasi sebagaimana dikenal adalah penyampaian/penyebar luasan informasi secara masif dan intensif kepada khalayak sasaran dengan menggunakan berbagai saluran komunikasi 
Ni Wayan Trisna Yundhari, A.A.I.N Marhaeni, dan I Gusti Bagus Indrajaya. Peran Sosialisasi...

seperti media massa, Melalui pendekatan persuasi, diupayakan untuk menggerakkan khalayak sasaran agar melakukan tercerahkan untuk mendaftarkan diri menjadi peserta program jaminan sosial bidang ketenagakerjaan. Keempat teknik ini dalam penerapannya saling terkait satu sama lain(BPJS Ketenagakerjaan,2016).

Menurut Kaliyaperumal (2004), tujuan pengukuran KAP adalah untuk mengetahui atau mengeksplorasi perubahan pada pengetahuan, sikap maupun tindakan pada komunitas atau para pekerja. Studi pada KAP ini akan memberikan informasi, rasa, dan tindakan, serta perilaku tentang apa yang orang ketahui tentang suatu hal. Menurut World Health Organization (2008), pengukuran KAP ini merupakan sebuah pedoman yang diciptakan untuk membantu mengumpulkan data yang nantinya digunakan untuk perencanaan, membenahi, dan mengevaluasi kinerja. Dengan cara mengetahui seberapa tinggi tingkat knowledge, attitude, dan practice, maka akan memudahkan dalam pembuatan program intervensi dalam bidang safe behavioryang akan disesuaikan dengan kebutuhan komunitas pekerja.

Adapun keragka konseptual dari penelitian ini adalah:

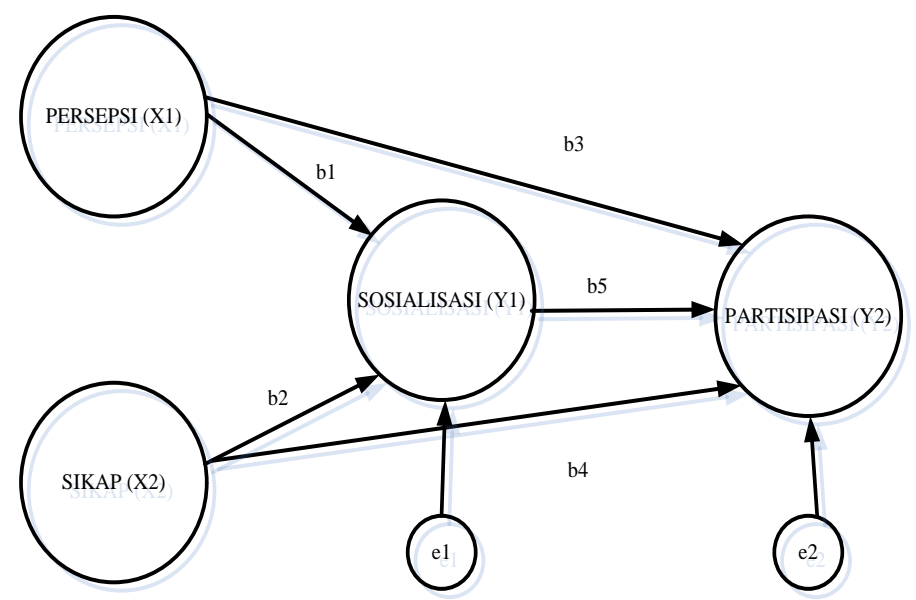


Berdasarkan pokok bahasan dan kajian pustaka yang diuraikan maka dapat dirumuskan hipotesis yang akan diuji pada penelitian ini yaitu :

$\mathrm{H}_{1} \quad$ : Persepsi buruh dan sikap buruh secara langsung berpengaruh positif dan signifikan terhadap keikutsertaan dalam sosialisasi layanan proteksi ketenagakerjaan di Kecamatan Blahbatuh, Kabupaten Gianyar.

$\mathrm{H}_{2}$ : Persepsi buruh, sikap buruh tentang layanan proteksi ketenagakerjaan, dan keikutsertaan dalam sosialisasi layanan proteksi ketenagakerjaan berpengaruh positif dan signifikan terhadap partisipasi buruh dalam layanan proteksi ketenagakerjaan di Kecamatan Blahbatuh, Kabupaten Gianyar.

$\mathrm{H}_{3} \quad$ : Peran keikutsertaansosialisasi layanan proteksi ketenagakerjaan dalam memediasi pengaruh persepsi dan sikap buruh tentang layanan proteksi ketenagakerjaan berpengaruh positif dan signifikan terhadap partisipasi buruh dalam layanan proteksi ketenagakerjaan di Kecamatan Blahbatuh, Kabupaten Gianyar.

\section{METODE PENELITIAN}

Dalam penelitian ini digunakan jenis data yang dikelompokkan menurut data kuantitatif dan Data Kualitatif. Data Kuantitatif adalah jenis data yang dapat diukur atau dihitung secara langsung, yang berupa informasi atau penjelasan yang dinyatakan dengan bilangan atau berbentuk angka, dalam penelitian ini berupa data Tenaga kerja Sektor Informal Non Pertanian di Kecamatan Blahbatuh, Kabupaten Gianyar, Perbandingan Keterlibatan Laki-laki dan Perempuan Pada Sektor Informal di Kabupaten Gianyar tahun 2011 - 2014, dan jumlah tenaga kerja sektor informal non pertanian yang mengikuti layanan proteksi ketenagakerjaan di Kecamatan Blahbatuh, Kabupaten Gianyar Tahun 2017.

Data Kualitatif adalah data yang disajikan dalam bentuk kata verbal bukan dalam bentuk angka, dalam penelitian ini adalah data persepsi buruh, sikap bururh, sosialisasi program, dan partisipasi buruh setelah mengikuti sosialisasi program layanan proteksi ketenagakerjaan 
Sumber data yang digunakan pada penelitian ini adalah data sekunder dan data primer.Sumber data sekunder adalah data yang langsung dikumpulkan oleh peneliti sebagai penunjang dari sumber pertama. Dapat juga dikatakan data yang tersusun dalam bentuk dokumen-dokumen, dalam penelitian ini adalah data-data yang didapatkan di Badan Pusat Statistik terkait data jumlah tenaga kerja sektor informal di Kcamatan Blahbatuh, Kabupaten Gianyar, perbandingan jumlah lakilaki dan perempuan pada sektor informal di Kabupaten Gianyar Tahun 20112014, dan jumlah tenaga kerja sektor informal non pertanian yang mengikuti layanan proteksi ketenagakerjaan di Kecamatn Blahbatuh, kabupaten Gianyar, serta melalui bentuk- bentuk yang telah diteliti oleh pihak lain seperti studi-studi empiris yang berkaitan dengan variabel terkait.

Data Primeradalah data yang dibuat oleh peneliti untuk maksud khusus menyelesaikan permasalahan yang sedang ditanganinya. Data dikumpulkan sendiri oleh peneliti langsung dari sumber pertama atau tempat objek penelitian dilakukan, dalam penelitian ini adalah data-data yang didapat melalui penyebaran kuisioner dan melakukan wawancara mendalam dengan narasumber yang bersangkutan.

Dalam penelitian ini digunakan beberapa variabel yakni Variabel eksogen atau variabel bebas dalam penelitian ini yaitu variabel Persepsi Buruh yang disimbolkan dengan X1 dan Sikap Buruh yang disimbolkan dengan X2.Variabel mediasi dalam penelitian ini yaituKeikutsertaan Buruh dalamSosilisasi Program yang dijalankann yang disimbolkan Y1.Variabel endogen atau variabel terikat 
dalam penelitian ini yaitu Partisipasti Buruh terhadap Program yang disimbolkan dengan Y2

Populasi dalam penelitian ini yakni populasi yang dimana seluruh tenaga kerja sektor infromalnon pertanianyang bertempat tinggal di Kecamatan Blahbatuh, Kabupaten Gianyar, Provinsi Bali yaitu pada tahun 2015 sebanyak 10.891 orang. Sampel dianggap sebagai perwakilan dari populasi yang hasilnya mewakili keseluruhan gejala yang diamati (Nata Wirawan, 2002). Cara penentuan sampel dapat dilakukan dengan rumus Slovin yaitu (Sugiono,2007):

$$
\mathrm{n}=\frac{N}{1+N e^{2}}
$$

keterangan:

$\mathrm{n}=$ ukuran sample

$\mathrm{N}=$ ukuran populasi

$\mathrm{e}=$ nilai kritis $(10 \%)$

Dengan menggunakan rumus di atas, maka didapat jumlah populasi untuk mengalisis partisipasi tenaga kerja sektor informal dalam mengikuti layanan proteksi ketenagakerjaan sebagai berikut:

$\mathrm{n}=\frac{N}{1+N e^{2}}$

$\mathrm{n}=\frac{10891}{1+(10891)(0.1)^{2}}$

$\mathrm{n}=99.09$ dibulatkan menjadi 99 orang.

Jadi, sampel yang digunakan pada Penelitian ini adalah sebanyak 99 orang tenaga kerja sektor informal yang diambil dari sembilan Desa yang terdapat di Kecamatan Blahbatuh, Kabupaten Gianyar .

Untuk menjamin terkumpulnya data yang sesuai dengan kebutuhan maka metode pengumpulan data yang perlu ditentukan dengan jelas. Metode 
pengumpulan data yang ditetapkan dalam penelitian ini yaitu observasi, interview dan wawancara mendalam.

Peneliti menggunakan teknik analisis data yaitu analisis jalur (path analysis). Analisis jalur dipergunakan karena didalam penelitian ini dirancang untuk menaksir hubungan kausalitas pada variabel yang berjenjang terhadap teori, sebelum digunakan analisis jalur, terlebih dahulu digunakan analisis faktor untuk mendapatkan skor faktor. Di dalam penelitian ini terdapat 1 variabel terikat, satu variabel mediasi dan dua variabel bebas.

\section{HASIL DAN PEMBAHASAN}

Buruh di Kecamatan Blahbatuh, Kabupaten Gianyar yang menjadi objek penelitian ini adalah 99 responden. Pengelompokan jenis kelamin ditunjukkan pada Tabel 1.

Berdasarkan Tabel 1. terlihat bahwa jumlah buruh laki-laki lebih banyak dari pada jumlah buruh perempuan, dikarenakan bekerja pada sektor informal memerlukan tenaga yang banyak, untuk mengambil pekerejaan buruh yang dianggap pekerjaan kasar, maka laki-laki dikatakan mampu mengambil pekerjaan itu karena dianggap memiliki tenaga yang lebih besar dari pada perempuan.

Tabel 1.

Jumlah Responden Buruh di Kecamatan Blahbatuh, Kabupaten Gianyar

\begin{tabular}{llcc}
\hline \multirow{2}{*}{ No } & \multirow{2}{*}{ Jenis kelamin } & \multicolumn{2}{c}{ Responden } \\
& Jumlah (orang) & Persentase (\%) \\
\hline 1 & Laki-laki & 87 & 87,87 \\
2 & Perempuan & 12 & 12,13 \\
& Total & 99 & 100 \\
\hline
\end{tabular}

Sumber: Hasil Penelitian, 2017 
Berdasarkan hasil penelitian yag dilakukan yang dilakukan di Kecamatan Blahbatuh, Kabupaten Gianyar, maka dapat diketahui jumlah responden menurut umur yang dapat dilihat pada Table 2 .

Tabel 4.2

Jumlah Responden Buruh di Kecamatan Blahbatuh, Kabupaten GianyarBerdasarkan Kelompok Umur

\begin{tabular}{cccc}
\hline \multirow{2}{*}{ No } & \multirow{2}{*}{ Umur } & \multicolumn{2}{c}{ Responden } \\
\hline 1 & $30-34$ & 3 & Persentase (\%) \\
2 & $35-39$ & 15 & 3,03 \\
3 & $40-44$ & 31 & 15,15 \\
4 & $45-49$ & 29 & 31,31 \\
5 & $50-54$ & 19 & 29,30 \\
6 & $55-60+$ & 2 & 19,19 \\
& Total & 99 & 2,02 \\
& & & 100 \\
\hline
\end{tabular}

Sumber: Hasil Penelitian, 2017

Berdasarkan Tabel 2. dapat diketahui bahwa dari 99 responden buruh di Kecamatan Blahbatuh, Kabupatn Gianyar yang paling banyak adalah berusia 40 44 tahun yaitu sebanyak 31 orang atau 31,31 persen, dikarenakan untuk bekerja pada sektor informal seperti buruh umur juga memengaruhi kuat - lemahnya tenaga buruh. Tingkat umur $40-44$ tahun ini dikatakan puncak tenaga yang sedang besar, karena pada umur itu tenaga sedang banyak. Seperti Kurva "U" terbalik semakin tinggi umur seseorang maka tenaga nya akan semakin lemah, sebaliknya umur 40-44 memiliki titik puncak tenaga besar.

Karakteristik responden berdasarkan tingkat pendidikan ditunjukkan dalam Tabel 3., tabel tersebut menjelaskan bahwa kelompok buruh tingkat pendidikannya berkisar dari tidak sekolah sampai perguruan tinggi/akademik. 
Tabel 3.

Jumlah responden Buruh Di Kecamatan Blahbatuh, Kabupaten Gianyar Berdasarkan Tingkat Pendidikan

\begin{tabular}{llcc}
\hline No & \multicolumn{1}{c}{ Tingkat Pendidikan } & Jumlah (orang) & Persentase (\%) \\
\hline 1 & Tidak Sekolah & 0 & 0 \\
2 & SD & 30 & 30,30 \\
3 & SMP & 45 & 45,46 \\
4 & SMA & 24 & 24,24 \\
5 & Perguruan Tinggi & 0 & 0 \\
& Jumlah & 99 & 100 \\
\hline
\end{tabular}

Sumber: Hasil Penelitian. 2017

Pada hasil penelitian ini responden yang berpendidikan SMP sebanyak 45,46 persen, hal ini disebabkan karena untuk bekerja pada sektor tenaga kerja (buruh) pendidikan tinggi tidak terlalu berpengaruh terhadap pekerjaan. Dimana yang dibutuhkan oleh buruh dalam bekerja adalah tenaga yang cukup banyak.

Pendapatan ialah penghasilan yang diterima atau jumlah uang yang diterima buruh di Kecamatan Blahbatuh, Kabupaten Gianyar dalam satu bulan yang dinyatakan dalam satuan rupiah. Pendapatan tersebut dihitung dari jumlah pendapatan buruh selama satu bulan. Pada Tabel 4.

Tabel 4.

Jumlah pendapatan Responden Buruh di Kecamatan Blahbatuh Selama Satu Bulan

\begin{tabular}{lccc}
\hline No & $\begin{array}{c}\text { Pendapatan Satu Bulan } \\
\text { (Rupiah) }\end{array}$ & $\begin{array}{c}\text { Responden } \\
\text { Jumlah }\end{array}$ & Persentase \\
\hline 1 & $<1000000$ & 0 & 0 \\
2 & $1000000-2000000$ & 43 & 43,43 \\
3 & $2000000-3000000$ & 56 & 56,57 \\
4 & $3000000-4000000$ & 0 & 0 \\
Total & & 99 & 100 \\
\hline
\end{tabular}

Sumber: Hasil Penelitian, 2017

Pada Tabel 4. dijelaskan bahwa rata-rata penghasilan buruh perbulan Rp 2.000.000 - 3.000.000 diperkirakan rata-rata jumlah harian yang diterima buruh berkisar antara Rp 60.000 - 80.000. Perbedaan jumlah pendapatan per bulan ini 
dikarena adanya kesamaan keahlian yang dimiliki oleh setiap buruh, karena tingkat keahlian dan kedisiplinan menjadi penilaian dalam pemberian upah.

Harga merupakan salah satu penentu keberhasilan keran harga menenentukan seberapa besar pendpatan yang akan diperoleh oleh buruh dari hasil kerja nya berupa jasa. Harga dalam penelitian ini berupa upah buruh yang ditetapkan oleh buruh di Kecamatan Blahbatuh, Kabupaten Gianyar diukur dalam satuan rupiah. Harga atau Upah dihitung per hari oleh Buruh dapat dilihat pada Tabel 5.

Tabel 5.

Jumlah Upah Buruh Per hari di Kecamatan Blahbatuh, Kabupaten Gianyar

\begin{tabular}{|c|c|c|c|}
\hline \multirow{2}{*}{ No } & \multirow{2}{*}{ Upah (Rupiah) } & \multicolumn{2}{|c|}{ Responden } \\
\hline & & Jumlah & Persentase (\%) \\
\hline 1 & $50000-60000$ & 13 & 13,13 \\
\hline 2 & $60000-70000$ & 24 & 24,24 \\
\hline 3 & $70000-80000$ & 33 & 33,33 \\
\hline 4 & $80000-90000$ & 29 & 29,30 \\
\hline Tota & & 99 & 100 \\
\hline
\end{tabular}
Sumber: Hasil Penelitian, 2017

Pada Tabel 5. dijelaskan bahwa jumlah upah buruh yang diterima per hari ini ditentukan berdasarkan kecekatan di dalam mengambil suatu pekerjaan dan ketetukan serta kedisiplinan buruh di dalam bekerja. Semakin rajin buruh bekerja makan upah yang diterima per hari nya akan semakin besar, selain itu tingkat keahlian buruh juga menjadi salah satu bidang adanya perbedaan upah.

Validitas dalam penelitian ini dijelaskan sebagi stau derajat ketepatan alat ukur penelitian tentang inti atau arti sebenarnya yang diukur. 
Tabel 6.

Hasil Uji Validitas

\begin{tabular}{llccc}
\hline No & \multicolumn{1}{c}{ Variabel } & $\begin{array}{c}\text { Koefisien } \\
\text { korelasi } \\
\text { (r hitung) }\end{array}$ & $\mathbf{r}_{\text {kritis }}$ & Simpulan \\
\hline $\mathbf{1}$ & Persepsi Buruh (X1) & & \\
& Keandalan & 0,899 & 0,3 & Valid \\
& Ketanggapan & 0,917 & 0,3 & Valid \\
& Keyakinan & 0,903 & 0,3 & Valid \\
& Empati & 0,911 & 0,3 & Valid \\
& Berujud & 0,855 & 0,3 & Valid \\
$\mathbf{2}$ & & & \\
& Pikap Buruh (X2) & 0,934 & 0,3 & Valid \\
& Ketangamanan dari pelayan & 0,901 & 0,3 & Valid \\
& Kemampuan petugas layanan proteksi & 0,926 & 0,3 & Valid \\
$\mathbf{3}$ & ketenagakerjaan & & & \\
& Sosialisasi (Y1) & & & \\
& Media informasi & 0,938 & 0,3 & Valid \\
& Cara Penyampaian & 0,940 & 0,3 & Valid \\
Kualitas sumer informasi & Partisipasi (Y2) & 0,987 & 0,3 & Valid \\
& Pemikiran & & & \\
& Uang & 0,855 & 0,3 & Valid \\
& Material & 0,900 & 0,3 & Valid \\
& Tenaga & 0,920 & 0,3 & Valid \\
\hline
\end{tabular}

Sumber: Data diolah, 2017

Berdasarkan Tabel 6. diketahui bahwa korelasi ( $\mathrm{r}_{\text {hitung }}$ ) antar skor item instrumen dengan skor total seluruh item pertanyaan dari $r_{\text {kritis }}(0,3)$. Jadi seluruh item instrumen dapat dinyatakan valid atau layak digukaan sebagai alat ukur.

Reliabilitas adalah derajat ketepatan, ketelitian atau keakuratan yang ditunjukkan oleh instrumen pengukuran dimana pengujiannya dapat dilakukan secara internal, yaitu dengan menganalisis konsistensi butir-butir yang ada. Hasil uji reliabilitas disajikan pada Tabel 7. 
Tabel 7.

Hasil Uji Reliabilitas

\begin{tabular}{cccl}
\hline \multicolumn{1}{c}{ No } & Variabel & $\begin{array}{c}\text { Cronbach's } \\
\text { Alpha }\end{array}$ & Simpulam \\
\hline 1 & Variabel Persepsi & 0,939 & Reliabel \\
2 & Variabel Sikap & 0,909 & Reliabel \\
3 & Variabel Sosialisasi & 0,951 & Reliabel \\
4 & Variabel partisipasi & 0,912 & Reliabel
\end{tabular}

Sumber: Data diolah, 2017

Tabel 7. menunjukkan bahwa nilai Cronbach's Alpha untuk setiap variabel lebih besar dari 0,70. Jadi dapat dinyatakan bahwa selururh variabel telah memenuhi syarat reliabilitas atau kehandalan.

Analisis Faktor Konfirmatoridalam penelitian digunakan untuk mengetahui validitas skor faktor antar indikator.

Tabel 8.

Nilai Validitas Persepsi

\begin{tabular}{lccc}
\hline \multicolumn{1}{c}{ Nilai Validitas } & $\begin{array}{c}\text { Cut } \text { - } \text { Off } \text { - } \\
\text { Value }\end{array}$ & Hasil Analsis & $\begin{array}{c}\text { Kete- } \\
\text { rangan }\end{array}$ \\
\hline KMO (Kaiser Meyer Olkin) & $\geq 0,50$ & 0,879 & Valid \\
X2 (Chi Square), $\alpha=0,05 ; \mathrm{df}=10$ & $\geq 18,31$ & 354,492 & Valid \\
Significance Probability & $<0,05$ & 0,000 & Valid \\
Eigen Value & $>1,00$ & 3,827 & Valid \\
Varians kumulatif & $\geq 60 \%$ & 76,533 & Valid \\
Anti Image & $\geq 0,50$ & 0,855 sampai dengan & Valid \\
Loading factor & $\geq 0,50$ & 0,853 sampai dengan & Valid \\
\end{tabular}

Sumber: Data diolah, 2017

Berdasarkan Tabel 8. menunjukkan bahwa semua kriteria penilaian tentang validitas persepsi terpenuhi (valid) sehingga dapat disimpulkan bahwa kelima faktor tersebut valid membentuk model persepsi. 
Tabel 9.

Nilai Validitas Sikap

\begin{tabular}{lccc}
\hline \multicolumn{1}{c}{ Nilai Validitas } & $\begin{array}{c}\text { Cut } \text { - } \text { Off } \text { - } \\
\text { Value }\end{array}$ & Hasil Analsis & $\begin{array}{c}\text { Kete- } \\
\text { rangan }\end{array}$ \\
\hline KMO (Kaiser Meyer Olkin) & $\geq 0,50$ & 0,747 & Valid \\
X2 (Chi Square), $\alpha=0,05 ; \mathrm{df}=3$ & $\geq 18,31$ & 163,005 & Valid \\
Significance Probability & $<0,05$ & 0,000 & Valid \\
Eigen Value & $>1,00$ & 2,451 & Valid \\
Varians kumulatif & $\geq 60 \%$ & 81,703 & Valid \\
Anti Image & $\geq 0,50$ & 0,732 sampai dengan & Valid \\
& $\geq 0,50$ & 0,896 sampai dengan & Valid \\
Loading factor & & 0,910 &
\end{tabular}

Sumber: Data diolah, 2017

Berdasarkan Tabel 9. menunjukkan bahwa semua kriteria penilaian tentang validitas sikap terpenuhi (valid) sehingga dapat disimpulkan bahwa ketiga faktor tersebut valid membentuk model sikap.

Tabel 4.10

Nilai Validitas Sosialisasi

\begin{tabular}{lcll}
\hline \multicolumn{1}{c}{ Nilai Validitas } & $\begin{array}{c}\text { Cut } \text { - } \text { Off } \text { - } \\
\text { Value }\end{array}$ & \multicolumn{1}{c}{ Hasil Analsis } & $\begin{array}{c}\text { Kete- } \\
\text { rangan }\end{array}$ \\
\hline KMO (Kaiser Meyer Olkin) & $\geq 0,50$ & 0,732 & Valid \\
X2 (Chi Square), $\alpha=0,05 ; \mathrm{df}=3$ & $\geq 18,31$ & 310,562 & Valid \\
Significance Probability & $<0,05$ & 0,000 & Valid \\
Eigen Value & $>1,00$ & 2,734 & Valid \\
Varians kumulatif & $\geq 60 \%$ & 91,125 & Valid \\
Anti Image & $\geq 0,50$ & 0,660 sampai dengan & Valid \\
Loading factor & $\geq 0,50$ & 0,810 & \\
\multicolumn{1}{c}{ Sumber: Data diolah, 2017} & & 0,939 sampai dengan & Valid \\
\hline
\end{tabular}

Berdasarkan Tabel 10. menunjukkan bahwa semua kriteria penilaian tentang validitas sosialisasi terpenuhi (valid) sehingga dapat disimpulkan bahwa ketiga faktor tersebut valid membentuk model sosialisasi.

Tabel 11.

Nilai Validitas Partisipasi

\begin{tabular}{|c|c|c|c|}
\hline Nilai Validitas & $\begin{array}{c}\text { Cut - Off - } \\
\text { Value }\end{array}$ & Hasil Analsis & $\begin{array}{c}\text { Kete- } \\
\text { rangan }\end{array}$ \\
\hline
\end{tabular}




\begin{tabular}{lclc}
\hline KMO (Kaiser Meyer Olkin) & $\geq 0,50$ & 0,760 & Valid \\
X2 (Chi Square), $\alpha=0,05 ; \mathrm{df}=6$ & $\geq 18,31$ & 325,425 & Valid \\
Significance Probability & $<0,05$ & 0,000 & Valid \\
Eigen Value & $>1,00$ & 3,253 & Valid \\
Varians kumulatif & $\geq 60 \%$ & 81,316 & Valid \\
Anti Image & $\geq 0,50$ & 0,730 sampai dengan & Valid \\
Loading factor & $\geq 0,50$ & 0,809 & \\
\multicolumn{1}{c}{ Sumber: Data diolah, 2017} & & 0,876 sampai dengan & Valid \\
\hline
\end{tabular}

Berdasarkan Tabel 11. menunjukkan bahwa semua kriteria penilaian tentang validitas partisipasi terpenuhi (valid) sehingga dapat disimpulkan bahwa ketiga faktor tersebut valid membentuk model persepsi.

Hasil Pengaruh Langsung, Pengaruh Tidak Langsung, dan Pengaruh Total antar variabel dalam penelitian ini dapat dijelaskan dalam Tabel 12 di bawah ini:

Tabel 12.

Hasil Pengaruh langsung, Pengaruh Tidak Langsung, dan Pengaruh Total antar variabel

\begin{tabular}{cccc}
\hline $\begin{array}{c}\text { Hubungan } \\
\text { Variabel }\end{array}$ & \multicolumn{2}{c}{ Pengaruh } & Total \\
\hline $\mathrm{X} 1 \rightarrow \mathrm{Y} 1$ & 0,408 & Tidak Langsung & \\
$\mathrm{X} 2 \rightarrow \mathrm{Y} 1$ & 0,389 & - & 0,408 \\
$\mathrm{X} 1 \rightarrow \mathrm{Y} 2$ & 0,229 & - & 0,389 \\
$\mathrm{X} 2 \rightarrow \mathrm{Y} 2$ & 0,184 & 0,251 & 0,480 \\
$\mathrm{Y} 1 \rightarrow \mathrm{Y} 2$ & 0,617 & 0,113 & 0,240 \\
\hline
\end{tabular}

Sumber: Hasil Penelitian 2017

Keterangan:

$$
\begin{array}{ll}
\mathrm{X} 1 & =\text { Perepsi } \\
\mathrm{X} 2 & =\text { Sikap } \\
\mathrm{Y} 1 & =\text { Sosialisasi } \\
\mathrm{Y} 2 & =\text { Partisipasi } \\
\mathrm{PL} & =\text { Pengaruh Langsung } \\
\mathrm{PTL} & =\text { Pengaruh Tidak langsung } \\
\mathrm{TP} & =\text { Total Pengaruh }
\end{array}
$$


Pada Tabel 12. dapat dijelaskan bahwa pengaruh langsung variabel X1 terhadap variabel $\mathrm{Y} 1$ ditunjukkan oleh $\mathrm{b}_{1}$ sebesar 0,408. Pengaruh langsung variabel X2 terhadap variabel Y1 ditunjukkan oleh $b_{2}$ sebesar 0,389. Pengaruh langsung variabel X1 terhadap Y2 ditunjukkan oleh $b_{3}$ sebesar 0,229. Pengaruh langsung variabel $\mathrm{X} 2$ terhadap variabel $\mathrm{Y} 2$ ditunjukkan oleh $\mathrm{b}_{4}$ adalah sebesar 0,184. Pengaruh langsung variabel Y1 terhadap Y2 ditunjukkan oleh $b_{5}$ adalah sebesar 0,617 .

Pengaruh tidak langsung variabel $\mathrm{X} 1$ terhadap variabel $\mathrm{Y} 2$ melalui variabel Y1 diperoleh dari $0,408 \times 0,617=0,251$. Pengaruh tidak langsung variabel X2 terhadap Y2 melalui variabel Y1 diperoleh dari $0,389 \times 0,617=$ 0,240. Uji sobel digunakan untuk menganalisis pengaruh variabel tidak langsung suatu variabel independen terhadap variabel dependen melalui variabel mediasi (Hukom, 2014).

Berdasarkan olah data menggunakan program SPSS hasil pengujian hipotesis langsung dalam penelitian ini dapat dijelaskan bahwa nilai t-hitung $(4,389)$ $>\mathrm{t}_{\text {-tabel }}(1,984)$ dan signifikansinya $0,000<0,05$, maka $\mathrm{H}_{0}$ ditolak yang berarti variabel persepsi buruh (X1) secara parsial berpengaruh positif dan signifikan terhadap keikutsertaan sosialisasi (Y1) dalam layanan proteksi ketenagakerjaan di Kecamatan Blahbatuh, Kabupaten Gianyar. Sebaliknya jika t-hitung $\leq$ t-tabel, maka $\mathrm{H}_{0}$ diterima yang berarti variabel persepsi buruh (X1) secara parsial tidak berpengaruh terhadap keikutsertaan sosialisasi (Y1) dalam layanan proteksi ketenagakerjaan di Kecamatan Blahbatuh, Kabupaten Gianyar. Hal ini diperkuat oleh penelitiandalam Hidayatullah (2014) Watick (1994) menyebutkan bahwa 
pengetahuan yang semakin baik dari akan memiliki persepsi yang baik terhadap sistem dan peningkatan informasi tentang layanan protksi ketenagakerjaan dan peraturan dapat meningkatkan persepsi keadilan dan kepatuhan.

Nilai t-hitung $(4,193)>$ nilai t-tabel $(1,984)$, maka $\mathrm{H}_{0}$ ditolak yang berarti variabel sikap buruh (X2) secara parsial berpengaruh positif dan signifikan terhadap keikutsertaan sosialisasi (Y1) dalam layanan proteksi ketenagakerjaan di Kecamatan Blahbatuh, Kabupaten Gianyar. Sebaliknya jika t-hitung $\leq$ t-tabel, maka $\mathrm{H}_{0}$ diterima yang berarti variabel sikap buruh (X2) secara parsial tidak berpengaruh terhadap keikutsertaan sosialisasi (Y1) dalam layanan proteksi ketenagakerjaan di Kecamatan Blahbatuh, Kabupaten Gianyar. Hal ini diperkuat oleh penelitian. Menurut Roesalya (2014) menyebutkan bahwa sikap memiliki pengaruh positif dan siginifikan terhadap kebelangsungan sosialisasi. Adanya sikap masyarakat yang bersikap positif terhadap suatu program akan berpengaruh positif terhadap Keikutsertaan Sosialisasi masyarakat untuk mengikuti suatu progran yang telah dibuat oleh pemerintah, dimana selain sikap masyarakat yang baik juga dipengaruhi oleh sikap pemerintah dalam melakukan sosialisasi agar masyarakat mengikuti sosilasisasi program.

Nilai $\mathrm{t}_{\text {hitung }}(4,095)>$ nilai $\mathrm{t}_{\text {tabel }}(1,984)$, maka $\mathrm{H}_{0}$ ditolak yang berarti variabel persepsi buruh (X1) secara parsial berpengaruh positif dan signifikan terhadap partisipasi buruh (Y2) dalam layanan proteksi ketenagakerjaan di Kecamatan Blahbatuh, Kabupaten Gianyar. Sebaliknya jika t-hitung $\leq$ t-tabel, maka $\mathrm{H}_{0}$ diterima yang berarti variabel persepsi secara parsial tidak berpengaruh terhadap partisipasi buruh (Y2) dalam layanan proteksi ketenagakerjaan di 
Kecamatan Blahbatuh, Kabupaten Gianyar. Menurut Ayunita dan Trisnani (2012) adanya persepsi masyarakat yang baik dapat menyebabkan partisipasi yang lebih tinggi.

Nilai $t_{\text {hitung }}(3,307)>$ nilai $t_{\text {tabel }}(1,984)$, maka $\mathrm{H}_{0}$ ditolak yang berarti variabel sikap buruh (X2) secara parsial berpengaruh positif dan signifikan terhadap partisipasii buruh (Y2) dalam layanan proteksi ketenagakerjaan di Kecamatan Blahbatuh, Kabupaten Gianyar. Sebaliknya jika t-hitung $\leq$ t-tabel, maka $\mathrm{H}_{0}$ diterima yang berarti variabel sikap buruh (X2) secara parsial tidak berpengaruh terhadap partisipasi buruh (Y2) dalam layanan proteksi ketenagakerjaan di Kecamatan Blahbatuh, Kabupaten Gianyar. Hal ini diperkuat dengan penelitian Aditama, dkk (2013)pengaruh yang signifikan antara sikap masyarakat terhadap partisipasi dalam pelaksanaan kegiatan siskamling di Kelurahan Labuhan Ratu Raya.

Nilai $t_{\text {hitung }}(10,998)>$ nilai $\mathrm{t}_{\text {tabel }}(1,984)$, maka $\mathrm{H}_{0}$ ditolak yang berarti variabel keikutsertaan sosialisasi (Y1) secara parsial berpengaruh positif dan signifikan terhadap partisipasi buruh (Y2) dalam layanan proteksi ketenagakerjaan di Kecamatan Blahbatuh, Kabupaten Gianyar. Sebaliknya jika t-hitung $\leq$ t-tabel, maka $\mathrm{H}_{0}$ diterima yang berarti variabel keikutsertaan sosialisasi (Y1) secara parsial tidak berpengaruh terhadap partisipasi buruh (Y2) dalam layanan proteksi ketenagakerjaan di Kecamatan Blahbatuh, Kabupaten Gianyar. Hasil penelitian dari Widnyani (2016) adanya partisipasi yang positif dilihat dari adanya keikutsertaan sosialisasi yang positif. Adanya keikutsertaan sosialisai yang tinggi akan mendorong adanya partisipasi yang meningkat pada masyarakat. 
Oleh karena $\mathrm{z}$ hitung $4>1,96$ maka berarti $\mathrm{H}_{0}$ ditolak dan $\mathrm{H}_{1}$ diterima. Dengan demikian peran keikutsertaan dalam sosialisasi (Y1) layanan proteksi ketenagakerjaan sebagai variabel mediasi hubungan sikap buruh (X2) terhadap partisipasi layanan proteksi ketenagakerjaan (Y2) di Kecamatan Blahbatuh, Kabupaten Gianyar.

\section{SIMPULAN DAN SARAN}

Berdasarkan tujuan penelitian dan pembahsasn hasil penelitian maka dapat disampaikan kesimpulan bahwa secara langsung untuk persamaan struktural pertama, persepsi buruh dan sikap buruh berpengaruh positif dan signifikan terhadap sosialisasi dalam mengikuti program layanan proteksi ketenagakerjaan di Kecamatan Blahbatuh, Kabupaten Gianyar.

Secara langsung untuk persamaan struktural kedua, persepsi buruh dan sikap buruh berpengaruh positif dan signifikan terhadap partisipasi dalam layanan proteksi ketenagakerjaan melalui keikutsertaan dalam Sosialisasi layanan proteksi ketengakerjaan di Kecamatan Blahbatuh, Kabupaten Gianyar.

Secara tidak langsung persepsi buruh dan sikap buruh berpengaruh positif dan signifikan terhadap partisipasi dalam layanan proteksi ketenagakerjaan melali keikutsertaan sosialisasi dalam layanan proteksi ketenagakerjaan di Kecamatan Blahbatuh, Kabupaten Gianyar.

Berdasarkan simpulan yang telah diuraikan maka dapat diajukan saran bahwa peneliti menyarankan kepada buruh agar dapat selalu mengikuti sosialisasi yang diadakan oleh pihak BPJS, karena msih kurang nya keterlibatan buruh untuk 
mengetahui penting nya layanan proteksi ketenagakerjaan untuk perlindungan diri di dalam bekerja yang tingkat mengalami kecelakaannya tinggi.

Peneliti juga menyarankan kepada buruh agar dapat memberitahukan kepada buruh yang lain atau teman-teman yang ada untuk selalu berpartisipasi didalam layanan prtoeksi ketenagakerjaan yang penting untuk perlindungan dii buruh.

Peneliti juga menyarankan agar buruh dapat memiliki persepsi dan sikap yang baik untuk berpartisipasi di dalam layanan proteksi ketenagakerjaan melaluai keikutertaan sosialisasi. Dimana dengan melihat upah yang didapat oleh buruh dapat dikatakan mampu untuk membayar iuran yang tersedia.

\section{REFERENSI}

Adam, Felecia,p. 2014. Keberagaman Sektor Informal Dalam Hubungannya Dengan Migrasi Masuk dan Remitan (Kasus Di Negeri Batu Merah, Kota Ambon). Piramida. Jurnal Ekonomi Kependudukan dan Sumber Daya Manusia.10[2], Hal.78-85. ISSN:1907-3275. Desember 2014.

Abdullah, Nurrudin. 2016. Pengaruh Status Sosial Ekonomi dan Sosialisasai Politik Melalui Media Massa Terhadap Partisipasi Politik Masyarakat Dlam Pemilu Legislatif Tahun 2014 Di Desa Sangatta Utara Kecamatan Sngatta Utara Kabupaten Kutai Timur. E-Journal Ilmu Pemerintahan, 4 (4), hal1627 - 1636.

Ajzen, I., \& Fishbein, M., 1980, Understanding Attitudes And Predicting Social Behavior, 83-111, Prentice-Hall, Englewood Scliffs, New York

Andreeyan, Rizal. 2014. Studi Tentang partisipasi Masyarakat dalam pelaksanaan Pembangunan di Kelurahan Smbutan, Kecamatan Sambuta, Kota Samarinda. E-Journal Administrasi Negara, 2 (4):1938-1951. Issn000000-ejournal.an.fisip-inmul.org

Badan Penyelenggara Jaminan Kesehatan (Bpjs). 2017 
Barrientos, Armando.2011. Social protection and poverty. Int J Soc Welfare 2011: 20: 240-249. United Nations Research Institute for Social Development (UNRISD),International Journal of Social Welfare 2011 Blackwell Publishing Ltd and the International Journal of Social Welfare. 11March.2011.http://onlinelibrary.wiley.com/doi/10.1111/ijsw.2011.20.iss ue-3/issuetoc, time12 January 2018, 11:23 PM

Bozkaya, Ant, Williamr. Kere.Desember 2009. Labor Regulations and European Private Quality. Harvard University and NBER. HBS Working Paper 08043.

Coxhead, ian dan Roshes Shrestha. 2016. Could a Resource Export Boom Reduce Workers'Earnings? The Labour-Market Channel in Indonesia. Bulletin of Indonesian Economic Studies. ISSN: 0007-4918 (Print) 1472-7234 (Online) Journal homepage: http://tandfonline.com/loi/cbie20

Danendra Putra, I Putu dan Sudirman, I Wayan. 2015. Pengaruh Modal Dan tenaga Kerja Terhadap Pendapatan Dengan Lama Usaha Sebagai Variabel Moderating. E-Jurmal EP Unud, 4(9),hal.1110-1139. ISSN:2303-0178. September 2015.

Dewi Utami, Ni Putu. 2014. Pengaruh Variabel Sosial Demografi Terhadap Keputusan Penduduk Lanjut Usia memilih Bekerja Di kecamatan Kediri.Jurnal Ekonomi Kuantitatif Terapan. 9[2]:135-141. Issn:23018968.

Emalia, Zulfa, dan Dewi Huntari. 2016. Willingness to Pay Masyaraakat terhadap Penggunaan Jasa Pengolahan Sampah. Jurnal Ekonomi Kuantitaif Terapan. Hal. 46-52. 9[1]. ISSN: 2301-8968. Februari 2016.

Henny Djuaeni, Gondodiputro sharon, pudji setiawan elsa.2010. Potensi Partisipasi Masyarakat Menuju Pelaksanaan Jaminan Kesehatan Dalam Rangka Universal Coverage Di Kota Bandung. Jurnal manajemen pelayanan kesehatan Vol.13, No. 3 september 2010. Hal:140-145

\section{ILO (Indonesian Labor Organization). Website}

Kaliyaperumal K. 2004. Guideline for conducting a knowledge, attitude and practice (KAP) Study. J AECS Illum 1:7-9

Mohd, Saidatulakmal. 2015. Provident fund for the informal sector:a case study of the informal sector worker in Kulaa Lumpur, Malaysia. Kajian Malaysia, vol : 33. Supp 1. Hal: 53-67. School of Sosial Science, Universiti Sains Malaysia, Malaysia. 
Nasrullah, Mohammad, Suwandi Tapto.2014. Hubungan Antara Knowledge, Attitude, Practice Safe Behavior Pekerja dalam upaya untuk menegakkan keselamatan dan kesehtaan kerja.The Indonesian Journal at Occptional Safety and Health, Vol:3, NO.1, 1 Januari-Juni. Hal: 82-93.

Notoatmodjo, S.2007. Promosi Kesehatan Dan Ilmu Perilaku. Rineka Cipta.Jakarta

Puspita Sari, Hardiyanti dan Setiarti Lilies.2015. Willingness To Pay Perbaikan Kualitas Pelayanan Kereta Api. Jurnal Ekonomi dan Studi Pembangunan. Vol: Vol. 16 (2), hal:200-209.Oktober 2015

OECD,France, and IZA, Germany.2014:12. Doil0.15105/izawol.12 may 2014.

Seftiani, Sar. 2010. Kontribusi Migran Terhadap Pertumbuhan Sektor Infromal Di Perkotaan (Kasus Di Jakarta Selatan). Piramida. Jurnal Ekonomi Kependdukan dan Sumber Daya Manusia. 6[2]. 15 November 2012

Sugiyono.2014.Metodologi Penelitian Bisnis.Bandung:Alfabeta

Ghozali, iman. 2013. Aplikasi Analisis Multivariate Dengan Program IBM SPSS 21. Semarang: Badan Penerbit Universitas Dipoegoro.

Hujo, Katja dan Elena Gaia. Social policy and poverty: an introduction. nt J Soc Welfare 2011: 20: 230-239 (C) 2011 United Nations Research Institute for Social Development (UNRISD), International Journal of Social Welfare. Blackwell Publishing Ltd and International Journal of Social Welfare. 13 April 2011. http://onlinelibrary.wiley.com/doi/10.1111/ijsw.2011.20.issue3/issuetoc, time12 January 2018, 11:23 PM

Hukom, Alexandra. 2014. Hubungan Ketenagakerjaan Dan Perubahan Struktur Ekonomi terhadap Kesejahteraan Masyarakat. Jurnal Ekonomi Kuantitaif Terapan. 7[2] Halaman 120-129. ISSN: 2301-8689. Agustus 2014.

Juvita Wowling, dkk.2015. Komunikasi Informasi, Edukasi (KIE) Sebagai Bentuk Sosialisasi Program Keluarga Berencana (KB) Di Kelurahan Tingkulu, Kecamatan Wamena Manado. Jurnal Acta Diurma. Volume IV.No.1.

Permata, Muhammad Rahmad. 2012. Analisa Ability To Pay dan Willingness To Pay Pengguna Jasa Kereta Api Bandara Soekarno Hatta - Manggarai. Jakarta : Universitas Indonesia. Diakses tanggal 29 Oktober 2013 pukul $00.07 \quad$ WIB. Diakses http://lib.ui.ac.id/opac/ui/detail.jsp?id=20315245\&lokasi=lokal. 
Puspita Sari, Hardiyanti dan Setiarti Lilies.2015. Willingness To Pay Perbaikan Kualitas Pelayanan Kereta Api. Jurnal Ekonomi dan Studi Pembangunan. Vol: Vol. 16 (2), hal:200-209.Oktober 2015

Ratiabriani, Ni Made, dan Ida Bagus Putu Purbadharmaja. 2016. Partisipasi Masyarakat Dalam Program Bank Sampah: Model Logit. Jurnal Ekonomi Kuantitaif Terapan. Hal. 53-58. 9[1]. ISSN: 2301-8968. Februari 2016.

Sato, Yuridan Arie Damayanti. 2015.Survey Of Recent Developments. Bulletin of Indonesian Economic Studies.ISSN: 0007-4918 (Print) 1472-7234 (Online)http://tandfonline.com/loi/cbie20

Sarah Cook dan jonathan Pincud. 2014. Poverty, Inequality and Social protection in Southeast Asia An Introduction. Journal Of Southeast Economics. Vol 31, No. 1pp1-17. ISSn: 2339-5206. April 2014

Rumiati, Khairul Fahmi dan Bambang Edison. 2013. Analisis Kemampuan dan Kemauan Membayar Tarif Angkutan Umum Mini Bus (SUPERBEN) di Kabupaten Rokan Hulu. Jurnal Online Teknik Sipil Universitas Pasir Pengaraian, Vol.1, No.1.

Scarpetta, Stefano.2014. Emploment Protections. IZA.OECD,France, and IZA, Germany.2014:12. Doil0.15105/izawol.12 may 2014.

Shahnewaz Khan, Md dan Tareq Muhammad Shamsul Arefin2. 2013. Safety Net, Social Protection, and Sustainable Poverty Reduction: A Review of the Evidences and Arguments for Developing Countries. IOSR Journal Of Humanities And Social Science (IOSR-JHSS) Volume 15 , Issue 2 (Sep. Oct. 2013), PP 23-29 e-ISSN: 2279-0837, p-ISSN: 2279-0845. www.Iosrjournals.Org,www.iosrjournals.org.http://onlinelibrary.wiley.com /doi/10.1111/ijsw.2011.20.issue-3/issuetoc, time12 January 2018, 11:23 $\mathrm{PM}$

Siagian, matias. 2012. Tingkat kepuasan Karyawan Perusahaan Swasta Dalam Pelayanan Jaminan Sosial Tenaga Kerja(Jamsostek). Jurnal Kesehatan Masyarakat vol: 7, No.5. Journal homepage:

Suwarna Madhukumar, Sudeepa D, Vaishali Gaikwad. 2012. Awareness and perception regarding health insurance in Bangalore rural population. International Journal of Medicine and Public health [Int. J. Med. Public health, Vol 2, Issue 2, 2012

Xue Dong, Sarah dan Chris Manning.2017. Labour Market Developments at a Time of Heightened Uncertainly. Bulletin of Indonesian Economic Studies. Volume 53, Issue 1. Page:1-25. 15 Juni 2017. http://tandfonline.com/doi/full/10.1080/00074918.2017.1326201 
Ni Wayan Trisna Yundhari, A.A.I.N Marhaeni, dan I Gusti Bagus Indrajaya. Peran Sosialisasi...

Widnyani, Ida Ayu Dewi dan ketut Alit Suardana. Pengaruh Sosialisasi, Sanksi, dan persepsi Akuntabilitas Terhadap Kepatuhan Wajib Pajak Dalam Membayar Pajak Kendaraan Bermotor. E -Journal Akuntansi Universitas Udayana. Vol. 16, No.3 September (2016) ISSn:2302-8556

Whitehead, John C. 2005. "Combining Willingness to Pay and Behavior Data with Limited Information”. Resource and Energy Economics, Vol.27, No.2, pp.143-155. 